\title{
Susceptibility of Rhipicephalus (Boophilus) microplus (Acari: Ixodidae) to pyrethroids and their associations in Pernambuco, Brazil
}

\author{
Susceptibilidade de Rhipicephalus (Boophilus) microplus (Acari: Ixodidae) a piretróides \\ e suas associações em Pernambuco, Brasil
}

Breno Barros de Santana ${ }^{1}$; Rafael Antonio Nascimento Ramos ${ }^{2,3}$; Marília de Andrade Santana ${ }^{3}$; Leucio Câmara Alves ${ }^{3}$; Gílcia Aparecida de Carvalho ${ }^{1 *}$

\begin{abstract}
${ }^{1}$ Unidade Acadêmica de Garanhuns, Universidade Federal Rural de Pernambuco - UFRPE, Garanhuns, PE, Brasil
${ }^{2}$ Dipartimento di Medicina Veterinaria, Università degli Studi di Bari, Valenzano, Bari, Italy

${ }^{3}$ Laboratório de Doenças Parasitárias dos Animais Domésticos, Departamento de Medicina Veterinária, Universidade Federal Rural de Pernambuco - UFRPE, Recife, PE, Brasil
\end{abstract}

Received December 13, 2012

Accepted April 18, 2013

\begin{abstract}
The synthetic pyrethroids and their associations have been widely used for controlling Rhipicephalus (Boophilus) microplus. The frequent use of acaricides has been inducing the development of resistance in the tick populations. The aim of this study was to assess the susceptibility of $R$. (B.) microplus populations to pyrethroids and their associations in the region of Garanhuns, Pernambuco, Brazil. In addition, the level of information among farm owners regarding tick control measures was investigated. Ticks were collected directly from naturally infested dairy cattle in the region and were exposed to pyrethroids and their associations. At the same time, an epidemiological questionnaire was applied with the aim of investigating the level of information among the farmers. The results reported here indicate that $R$. (B.) microplus populations in the dairy region of Garanhuns show resistance to pyrethroids and their associations, except when the product is associated with piperonyl butoxide. Regarding the results from the epidemiological survey, it was seen that there is a considerable lack of information among the farmers in relation to ixodid control measures. The level of ticks resistance to acaricides varied widely across the region studied. No alternative control programs have been implemented among these farms, thus demonstrating that there is a need for more information relating to the biology and control of $R$. (B.) microplus.
\end{abstract}

Keywords: Ticks, resistance, acaricide, in vitro test, bovine, microregion of Garanhuns.

\section{Resumo}

Os piretróides sintéticos e associaçóes são acaricidas amplamente utilizados para o controle do Rhipicephalus (Boophilus) microplus. O uso frequente destes fármacos tem induzido o surgimento de populaçôes de carrapatos resistentes. Objetivou-se neste estudo avaliar a susceptibilidade de populaçóes de $R$. (B.) microplus aos piretróides e associações. Além disso, investigou-se o nível de informaçôes dos proprietários com relação às medidas de controle utilizadas. Os carrapatos foram coletados diretamente de bovinos naturalmente infestados na região leiteira de Garanhuns, Pernambuco e expostos a piretróides e suas associaçôes. Contemporaneamente, foi aplicado um questionário epidemiológico com o objetivo de avaliar o nível de informação dos produtores. Os resultados aqui obtidos demonstram que populaçóes de $R$. (B.) microplus provenientes da regiáo leiteira de Garanhuns apresentam resistência aos piretróides, exceto quando o produto está associado com butóxido de piperonila. Em se tratando dos resultados referentes ao inquérito epidemiológico, verificou-se considerável falta de informação por parte dos produtores com relação às medidas de controle de ixodídeos. Assim, verifica-se que o nível de resistência aos acaricidas é muito variável na região estudada e que não há, nas propriedades, a adoção de programas alternativos de controle, demonstrando a necessidade de maiores informaçóes relacionadas à biologia e ao controle do $R$. (B.) microplus.

Palavras-chave: Carrapatos, resistência, acaricida, teste in vitro, bovino, microrregiáo de Garanhuns.

*Corresponding author: Gílcia Aparecida de Carvalho

Unidade Acadêmica de Garanhuns, Universidade Federal Rural

de Pernambuco - UFRPE, Av. Bom Pastor, $s / n$,

Boa Vista, CEP 55292-270, Garanhuns, PE, Brasil

e-mail: gilciasilva@yahoo.com.br 


\section{Introduction}

Rhipicephalus (Boophilus) microplus (Canestrini, 1888) is considered the main tick species affecting cattle in tropical and subtropical areas (MURRELL; BARKER, 2003; CANÇADO et al., 2009). Its importance is related to several types of harm that it causes to these animals, such as reduction in productivity (MARQUES, 2006) and transmission of pathogens (DANTASTORRES, 2007).

Currently, its control is based on use of chemical acaricides (SILVA, 2008). Intensive use of acaricides has been inducing the development of resistant $R$. (B.) microplus populations (CAMPOS JÚNIOR; OLIVEIRA, 2005; GOMES et al., 2011). This resistance may be developed due to increased gene expression or enzyme activity, as well as neuroreceptor and sodium channel mutations that impede penetration by these chemical products (MARTIN et al., 2003; OAKESHOTT et al., 2003).

Ticks resistance has been reported in various countries (LI et al., 2004; ROSADO-AGUILAR et al., 2008), including Brazil (CAMPOS JÚNIOR; OLIVEIRA, 2005; GOMES et al., 2011), where, there are reports in Rio Grande do Sul (PATARROYO; COSTA, 1980), Minas Gerais, Bahia and Espírito Santo (LEITE et al., 1995), and São Paulo (SOARES et al., 2001). In the state of Pernambuco, Santana et al. (2001) verified that synthetic pyrethroids and amitraz showed lower effectiveness, whereas organophosphates and carbamates displayed good action.

Considering this phenomenon of resistance, tick control should be based on prudent and rational use of acaricides coupled with environmental management. Moreover, actions to provide better information are also needed in order to achieve better understanding with regard to correct use of these chemicals products. Therefore, the aim of the present study was to assess the susceptibility of $R$. (B.) microplus populations to pyrethroids and their associations. In addition, the level of information among farmers regarding control strategies against this ixodid was investigated.

\section{Materials and Methods}

\section{Ticks and study area}

From August 2010 to July 2011, engorged females of $R$. (B.) microplus (150 specimens on each farm) were collected from naturally infested cattle from the municipalities of Caetés, Canhotinho, Garanhuns, São João, Brejão, Terezinha and Bom Conselho, located in the dairy region of Garanhuns, state of Pernambuco. In each municipality, two farms were evaluated. The area studied is characterized by a mild climate during the summer and low temperatures in the winter. The mean annual temperature is about $20{ }^{\circ} \mathrm{C}$ and high precipitation is observed between April and June. Over the same period (April - June) higher numbers of engorged females of $R$. (B.) microplus are detected on the animals. The diet of these cattle is based on Bermuda grass and Elephant grass. During the dry season, forage cactus is also used.

\section{Acaricide tests}

The ticks were subjected to the "Adult Immersion Test" (AIT) (DRUMMOND et al., 1973), which is an in vitro resistance detection assay. The following commercial acaricides based on pyrethroids and their associations were used: 1) cypermethrin $20.0 \mathrm{~g}+$ chlorpyrifos $50.0 \mathrm{~g}$; 2) cypermethrin $15.0 \mathrm{~g}+$ chlorpyrifos $25.0 \mathrm{~g}+$ citronellal $1.0 \mathrm{~g}$ and 3) cypermethrin $15.0 \mathrm{~g}+$ chlorpyrifos $25.0 \mathrm{~g}+$ piperonyl butoxide $15.0 \mathrm{~g}+$ citronellal $1.0 \mathrm{~g}$. The dilution of the products were realized following the manufacturer's instructions.

Ten engorged females (per group) with homogeneous weight were placed in Petri dishes. The test groups were immersed in the acaricides for five minutes and the controls were immersed in distilled water. The females were maintained in an incubator under controlled conditions $\left(26 \pm 1{ }^{\circ} \mathrm{C}, 80 \pm 5 \%\right.$ relative humidity and scotophase), for 16 days to lay eggs. After this had taken place, the eggs were placed in individual $10 \mathrm{~mL}$ glass vials, which were closed with a cotton plug and kept in the incubator under controlled conditions (see above).

The acaricide efficiency (AE) was obtained using the following parameters: engorged female weight, eggs weight and eggs hatching percentage. The commercial products were considered to be efficient if $\mathrm{AE} \geq 95 \%$ (DRUMMOND et al., 1973).

\section{Epidemiological questionnaire}

Simultaneously with the tick collection, an epidemiological survey was conducted in order to investigate the level of information among the farmers. They were asked about the main problems in the herd, the level of tick infestation (i.e. low infestation: $<20$ engorged females/animal; moderate infestation: from 21 to 50 engorged females/animal; high infestation: > 50 engorged females/animal), the degree of production loss and the tick control measures used, such as the acaricide used, frequency of use, instructions for use and alternative control measures.

\section{Results and Discussion}

\section{Acaricide tests}

The overall results from the acaricide efficacy tests (Adult Immersion Test) are reported in Table 1.

The present study demonstrated that in the microregion of Garanhuns, state of Pernambuco, $R$. (B.) microplus showed resistance to pyrethroids and their associations, except when associated with piperonyl butoxide. Particularly, the tick populations in Caetés and Canhotinho did not show any resistance to any of the acaricides formulations studied.

According to Mendes et al. (2007), Koller et al. (2009), Camillo et al. (2009) and Gomes et al. (2011), resistance to these compounds is widespread in Rio Grande do Sul, Paraná, Mato Grosso do Sul, São Paulo, Minas Gerais and Rio de Janeiro. Tick populations resistant to various acaricide groups have also been 
Table 1. Mean efficacy (\%) of commercial acaricides formulations based on pyrethroids and their associations, against Rhipicephalus (Boophilus) microplus in the dairy region municipalities of Garanhuns, Pernambuco, Brazil, from August 2010 to July 2011.

\begin{tabular}{lccc}
\hline \multirow{2}{*}{ Municipalities } & \multicolumn{3}{c}{ Acaricides / Efficacy (\%) } \\
\cline { 2 - 4 } & cypermethrin + chlorpyrifos (\%) & $\begin{array}{c}\text { cypermethrin + chlorpyrifos + } \\
\text { citronellal (\%) }\end{array}$ & $\begin{array}{c}\text { cypermethrin + chlorpyrifos + } \\
\text { piperonyl butoxide + citronellal (\%) }\end{array}$ \\
\hline Caetés & 99.73 & 98.70 & 100 \\
Canhotinho & 99.79 & 99.40 & 100 \\
Garanhuns & 78.75 & 95.95 & 100 \\
Sáo João & 90.30 & 77.91 & 100 \\
Brejão & 57.08 & 84.15 & 100 \\
Terezinha & 56.61 & 68.33 & 100 \\
Bom Conselho & 55.82 & 70.35 & 100 \\
\hline
\end{tabular}

$\%$ - percentage.

detected in other regions of the country, including the northeastern region (SANTANA et al., 2001; SILVA et al., 2005).

The main chemical used in this study (cypermethrin) was shown to be very effective during the 1980s (PEREIRA; LUCAS, 1987). However, widespread use has reduced its effectiveness over time, with reports of low efficacy, i.e. as low as 40\% (SOUZA et al., 2003). The efficacy values obtained in the present study (Table 2) demonstrated that $R$. (B.) microplus from various locations was resistant to cypermethrin, following the same profile as previously observed (SOUZA et al., 2003).

The results from the present study demonstrated that acaricides containing organophosphates were effective in controlling $R$. (B.) microplus when combined with piperonyl butoxide. A similar result was observed by Koller et al. (2009) in Mato Grosso do Sul, with $100 \%$ efficiency when a combination of cypermethrin and chlorpyrifos with piperonyl butoxide and citronellal was used.

The incorrect use of acaricides has contributed towards the process of induction of tick resistance to various chemical bases and has allowed occurrences of cross-resistance, as reported in Mexico by Amendáriz-González (2003). A similar situation has been seen to occur in Brazil regarding tick control (ROCHA et al., 2006; FARIAS et al., 2008) and management and control of the horn fly (Haematobia irritans) (BARROS, 2005; BARROS et al., 2007). In this case, because of the unspecific nature of most of the products used, controlling one species may interfere with the susceptibility of another species. In addition to the numerous factors mentioned above, it is important to highlight that $R$. (B.) microplus may present resistance faster than seen in other tick species, due to the shorter time between generations.

Interestingly, in this study, it was also observed that pyrethroids and their associations were effective on farms where rotational grazing was implemented, thus demonstrating the importance of alternative control measures.

\section{Epidemiological questionnaire}

Regarding the results from the questionnaire applied, there was a lack of information among the farmers, since in most cases the control measures adopted were implemented erroneously.

From applying the epidemiological questionnaire, it was observed that the degree of tick infestation among the animals was high on $40 \%$ of the farms, moderate on $34 \%$ and low on $26 \%$. The spraying method (60\%) was most frequently used on the farms for applying the acaricides, followed by the injectable method (40\%). Application of acaricides through a spray is an important factor that accelerates resistance (BIANCHI et al., 2003; BARROS et al., 2007), because when spraying is not carried out properly, the tick population receives an underdose of acaricide and resistant populations are thus selected.

The chemical groups most frequently used by the farmers were associations of organophosphate and pyrethroid, followed by macrocyclic lactones and formamidines, with rates of $47 \%$, $40 \%$ and $13 \%$, respectively. The lack of knowledge among the farmers regarding the main chemical groups induced use of a wide variety of acaricides with the same active agent, in which only the commercial name was changed. Intense use of macrocyclic lactones and pyrethroids was noted in the present study. On the other hand, rotation of chemical bases without any criteria for doing so exposed the ticks to all the chemical groups available on the market, thus favoring selection of multiresistant tick populations. According to Martins et al. (2005), a chemical group should only be changed if the treated population is able to survive and perform oviposition with fertile eggs. Generally, the period between changes should not be less than two years. Based on this evidence, associations of chemical groups available on the market (e.g. pyrethroids and organophosphates) can be used in order to avoid selection of resistant ticks (MARTINS et al., 2005).

When the farmers were asked about their frequency of use of acaricides, $26 \%$ reported that application of the acaricide was performed at intervals of 60 days, $20 \%$ at intervals of 30 days, $20 \%$ at intervals of 21 days, $20 \%$ weekly and $14 \%$ only when tick infestations were detected visually. Regarding the effectiveness of control, $53 \%$ of the farmers reported good levels of control, and $47 \%$ fair control. With regard to environmental management, only $7 \%$ of the farms were practicing some alternative form of control, in relation to their facilities or the environment. Rotational grazing was the only environmental management reported by the farmers.

Alternative control measures such as care facilities and rotational grazing can be implemented in order to reduce the infestation level of ectoparasites in the environment and consequently reduce parasitism in the animals. The absence of these measures among the farms studied may also have contributed towards the low levels of pesticide efficacy observed. 


\section{Conclusions}

The level of resistance of the ticks to commercially available acaricides formulations studied here (1. cypermethrin $20.0 \mathrm{~g}+$ chlorpyrifos $50.0 \mathrm{~g}$; 2 . cypermethrin $15.0 \mathrm{~g}+$ chlorpyrifos $25.0 \mathrm{~g}+$ citronellal $1.0 \mathrm{~g} ; 3$. cypermethrin $15.0 \mathrm{~g}+$ chlorpyrifos $25.0 \mathrm{~g}+$ piperonyl butoxide $15.0 \mathrm{~g}+$ citronellal $1.0 \mathrm{~g}$ ) varied widely across the dairy region of Garanhuns. The results regarding the levels of resistance of $R$. (B.) microplus to the acaricides tested are probably related to indiscriminate use of products based on pyrethroids and associations, and absence of any strategic control program, thus demonstrating the need for more information for farmers regarding the biology and control of this tick species.

Unfortunately, the data described here follow the same pattern as seen in other regions of Brazil. Therefore, there is a need for veterinarians to implement actions that also focus on education in the field regarding correct and rational use of acaricides. In addition, use of environmental control measures should be encouraged.

\section{References}

Amendáriz-González I. Informe de un caso de resistencia múltiple a ixodicidas en Boophilus microplus Canestrini (Acari: Ixodidae) en Tamaulipas, México. Vet Méx 2003; 34(4): 397-401.

Barros ATM. Aspectos do controle da mosca-dos-chifres e manejo de resistência. Corumbá: Embrapa Pantanal; 2005. 23 p. (Embrapa Pantanal. Documento, n. 77).

Barros ATM, Gomes A, Koller WW. Insecticide susceptibility of horn flies, Haematobia irritans (Diptera: Muscidae), in the State of Mato Grosso do Sul, Brazil. Rev Bras Parasitol Vet 2007; 16(3): 145-151. PMid:18078601. http://dx.doi.org/10.1590/S1984-29612007000300006

Bianchi MW, Barré N, Messad S. Factors related to cattle level infestation level and resistance to acaricides in Boophilus microplus tick populations in New Caledonia. Vet Parasitol 2003; 112(1-2): 75-89. http://dx.doi. org/10.1016/S0304-4017(02)00415-6

Camillo G, Vogel FF, Sangioni LA, Cadore GC, Ferrari R. Eficiência in vitro de acaricidas sobre carrapatos de bovinos no estado do Rio Grande do Sul, Brasil. Cienc Rural 2009; 39(2): 490-495. http://dx.doi. org/10.1590/S0103-84782008005000082

Campos Júnior DA, Oliveira PR. Avaliação in vitro da eficácia de acaricidas sobre Boophilus microplus (Canestrini, 1887) (Acari: Ixodidae) de bovinos no município de Ilhéus, Bahia, Brasil. Cienc Rural 2005; 35(6): 1387-1392. http://dx.doi.org/10.1590/S010384782005000600025

Cançado PHD, Zucco CA, Piranda EM, Faccini JLH, Mourão GM. Rhipicephalus (Boophilus) microplus (Acari: Ixodidae) as a parasite of pampas deer (Ozoctoceros bezoarticus) and cattle in Brazil's Central Pantanal. Rev Bras Parasitol Vet 2009; 18(1): 42-46. PMid:19500460. http://dx.doi.org/10.4322/rbpv.01801008

Dantas-Torres F. Rocky Mountain spotted fever. Lancet Infect Dis 2007; 7(11): 724-732. http://dx.doi.org/10.1016/S14733099(07)70261-X

Drummond RO, Ernst SE, Trevino JL, Gladney WJ, Graham OH. Boophilus annulatus and Boophilus microplus: laboratory tests of insecticides. J Econ Entomol 1973; 66(1): 130-133. PMid:4690254.
Farias NA, Ruas JL, Santos TRB. Análise da eficácia de acaricidas sobre o carrapato Boophilus microplus, durante a última década, na região sul do Rio Grande do Sul. Cienc Rural 2008; 38(6): 1700-1704. http://dx.doi. org/10.1590/S0103-84782008000600032

Gomes A, Koller WW, Barros ATM. Suscetibilidade de Rhipicephalus (Boophilus) microplus a carrapaticidas em Mato Grosso do Sul, Brasil. Cienc Rural 2011; 41(8): 1447-1452. http://dx.doi.org/10.1590/S010384782011005000105

Koller WW, Gomes A, Barros ATM. Diagnóstico da resistência do carrapato-do-boi a carrapaticidas em Mato Grosso do Sul. Campo Grande: Embrapa; 2009. 47 p. (Boletim de Pesquisa e Desenvolvimento / Embrapa Gado de Corte). Dados eletrônicos.

Leite RC, Labruna MB, Oliveira PR, Monteiro AMF, Caetano Júnior J. In vitro susceptibility of engorged females from different populations of Boophilus microplus to comercial acaricides. Rev Bras Parasitol Vet 1995; 4(2) Supl. 1: 283-294.

Li AY, Davey RB, Miller RJ, George JE. Detection and characterization of amitraz resistance in the southern cattle tick, Boophilus microplus (Acari: Ixodidae). J Med Entomol2004; 41(2): 193-200. PMid:15061278. http:// dx.doi.org/10.1603/0022-2585-41.2.193

Marques DC. Criaçấo de Bovinos. 7. ed. Belo Horizonte: Consultoria Veterinária e Publicaçóes; 2006. 586 p.

Martin T, Ochou OG, Vaissayre M, Fournier D. Oxidases responsible for resistance to pyrethroids sensitize Helicoverpa armigera (Hubner) to triazophos in West Africa. Insect Biochem Mol Biol 2003; 33(9): 883-887. http://dx.doi.org/10.1016/S0965-1748(03)00093-6

Martins JRS, Furlong J, Prata MCA. Carrapato: problemas e soluçóes Juiz de Fora: Embrapa Gado de Leite; 2005. 65 p.

Mendes MC, Pereira JR, Prado AP. Sensitivity of Boophilus microplus (Acari: Ixodidae) to pyrethroids and organophosphate in farms in the Vale do Paraíba region, São Paulo, Brazil. Arq Inst Biol 2007; 74(2): 81-85.

Murrell A, Barker SC. Synonymy of Boophilus Curtice, 1891 with Rhipicephalus Koch, 1844 (Acari: Ixodidae). Syst Parasitol 2003; 56(3): 169-172. PMid:14707501. http://dx.doi. org/10.1023/B:SYPA.0000003802.36517.a0

Oakeshott JG, Home I, Sutherland TD, Russell RJ. The genomics of insecticide resistance. Genome Biol 2003; 4(1): 202. PMid:12540295 PMCid:151287. http://dx.doi.org/10.1186/gb-2003-4-1-202

Patarroyo JH, Costa JO. Susceptibility of Brazilian samples of Boophilus microplus to organophosphorus acaricides. Trop Anim Health Prod 1980; 12(1): 6-10. PMid:6154364. http://dx.doi.org/10.1007/ BF02242623

Pereira MC, Lucas R. Estudo in vitro da eficiência de carrapaticidas em linhagem de Boophilus microplus (Canestrini, 1887) proveniente de Jacareí, Estado de São Paulo, Brasil. Rev Fac Med Vet Zootec Univ São Paulo 1987; 24(1): 7-11.

Rocha CMBM, Oliveira PR, Leite RC, Cardoso DL, Calic SB, Furlong J. Percepçáo dos produtores de leite do município de Passos, MG, sobre o carrapato Boophilus microplus (Acari: Ixodidae), 2001. Cienc Rural 2006; 36(4): 1235-1242. http://dx.doi.org/10.1590/S010384782006000400029

Rosado-Aguilar JA, Rodriguez-Vivas RI, Garcia-Vazquez Z, FragosoSanchez H, Ortiz-Najera O, Rosario-Cruz R. Development of amitraz resistance in field populations of Boophilus microplus (Acari: Ixodidae) undergoing typical amitraz exposure in the Mexican tropics. Vet 
Parasitol 2008; 152(3-4): 349-353. PMid:18242859. http://dx.doi. org/10.1016/j.vetpar.2007.12.026

Santana VLA, Faustino MAG, Lima MM, Furlong J, Alves LC. Situação do controle químico do Boophilus na zona da mata e Agreste do Estado de Pernambuco. Cienc Vet Trop 2001; 4(2-3): 281-290.

Silva WW, Athayde ACR, Araújo GMB, Santos VD, Silva Neto AB. Resistência de fêmeas ingurgitadas de Boophilus microplus e Rhipicephalus sanguineus (Acari: Ixodidae) a carrapaticidas no semi-árido paraibano: efeito da cipermetrina e do amitraz. ACSA - Agrop Cient SemiArido 2005; 1(1): 59-62.
Silva HC. Parâmetros farmacocinéticos e atividade endectocida de uma nova formulação contendo avermectinas, via tópica (pour-on), em bovinos, Jaboticabal [Dissertação]. Jaboticabal: Universidade Estadual Paulista; 2008. 120 p.

Soares VE, Silveira DM, Nunes TLS, Oliveira GP, Barbosa OF, Costa AJ. Análise in vitro da açáo de carrapaticidas em cepas de Boophilus microplus (Canestrini, 1887) colhidas de bovinos leiteiros da região Nordeste do estado de São Paulo. Semina: Cienc Agrárias 2001; 22(1): 85-90.

Souza AP, Sartor AA, Bellato V, Perussolo S. Eficácia de carrapaticidas em rebanhos de bovinos leiteiros de municípios da região Centro-Sul do Paraná. Rev Cie Agrovet 2003; 2: 245-250. 